\title{
Is Listed Corporates Financial Performance Vulnerable? ROE Factors measurement Using DuPont Formula
}

\author{
Pascal Ricordel ${ }^{1}$ and Melinda Majlath ${ }^{2}$
}

\begin{abstract}
It's been 10 years since the last financial crisis, and the rising in stock market price along with record dividends raises deep concerns about the sustainability of listed corporate financial performance. Has the narrow logic of shareholder value been compromising long term financial performance leading to a financial crisis? We question here the DuPont equation to track financial performance drivers over time for discussing about its vulnerability. A disaggregated five-steps DuPont equation is used to set up following drivers: operational profitability, asset turnover, leverage multiplier, interest and fiscal burden. We draw a statistical analysis of those drivers with a panel data of 43 international non-financial corporates from France, Germany, Hungary and Italy between 2012 and 2017. The results stress the role of fiscal burden, interest burden and operational profit as the main ROE driver. Leverage multiplier driver, consensually considered as more financially vulnerable, has played an astonishing negative role. The drop in asset turnover is however the more worried signal as this factor is the most sustainable.
\end{abstract}

Keywords: ROE components, DuPont equation, Financial sustainability, Listed corporate performance, Financial reporting

\section{Introduction}

Concerns are growing about the recent financial market boost $(+65.5 \%$ for CAC 40 index between 2012 and 2017) and the record dividends (+24.5\%), questioning the vulnerability of the recent financial performance of listed corporates. They are echoing the 2001 and 2008 crisis that demonstrated the vulnerability of performance boosters as leverage multiplier and interest rate. Has the narrow logic of shareholder value been compromising other stakeholder interest and corporates long term performance heading business to a crisis? The vulnerability issue has reignited the debate between the classical doctrine vision (Friedman, 1970; Porter and Kramer, 2011) that corporates performance is shareholders and short termism oriented and on the other hand, the stakeholder theory (Jensen, 2001; Waal, 2008) stressing that companies embeds a long term shareholder value creation. Some researches on this issue suggests that sustainability in business is on the way (Epstein et al, 2001; Soppe, 2009), embedded in a more integrated process-decision framework (Kiran and Sharma, 2011; Rezaee, 2016), with a positive relationship between CSR and financial performance (Galant and Simon, 2017) and a self-enforcement code of conduct in good governance (Deloitte white paper, 2016). Sustainability indexes or formula (Dow Jones Sustainability Index, Sustainable Growth DuPont) are used in investor strategy (Sabbaghi et al, 2016), and it is a matter of facts that corporate sustainability has been driven by large corporations (Lozano, 2015).

\footnotetext{
| ${ }^{1}$ Associate professor, Business and Administration Management Department, Edhen, Université Le HavreNormandie, France

${ }^{2}$ Associate professor, Institute of Economics and Social Sciences, Keleti Faculty of Business and Administration, Óbuda University, Budapest, Hungary
} 
Nonetheless, researches don't specifically focus on the recent rising in corporate financial performance that needs some empirical investigation about its robustness/vulnerability. If corporate finance performance is sustainable, in the broadly accepted sense of environment, social and governance care, this sustainability should be reflected in drivers strategically selected by big corporates for boosting their ROE performance. Robust drivers, like profitability and efficiency should empirically be more significant than opportunistic drivers like leverage, interest and fiscal burden.

Our study tracks the DuPont equation components in order to highlight which drivers have boosted the recent financial performance shedding some light on the strength and weakness of the recent financial performance. Shaped in 1919 by E.I du Pont de Nemours, the DuPont equation breakdowns financial statements explaining the return on equity (ROE) (Chandler, 1977). It provides an excellent framework for getting a quick overview of corporate strengths and weaknesses. The DuPont equation has largely been using by practitioners for explaining the corporate financial performance and by scholars to study sectors of activity (Burja and Marginean R, 2014; Kijewska, 2016). When dealing with specific sustainable issue, either the DuPont formula should be transformed into the sustainable growth DuPont formula, with a "sustainability" oriented meaning of constant capital resource, or should be enlarged in a more integrated framework (Castro and Chousa, 2006) to introduce a larger list of drivers specifically related with a "sustainability" dimension like environment, social or governance.

Using the DuPont conventional five-steps formula as a first approach to track vulnerability signals in the financial performance makes sense. The DuPont equation breaks down ROE in operational profit margin, asset turnover, leverage multiplier, interest burden, fiscal burden, drivers that are not ranking the same in vulnerability (section 2). The broad adoption of IFRS financial statement by listed companies provides data homogenous enough to process an empirical statistical analysis of the ROE drivers in the DuPont equation. We have built metrics for 43 non-financial corporates from France, Germany, Hungary and Italy using accounting and management data on the 2012-2017 period to analysis the performance drivers (section 3). Analysis results (section 4) stress the significant role of fiscal, interest burden and operational profit in explaining ROE when considering variation during the period. The leverage multiplier, a vulnerable driver is not significant while the drop in asset turnover appears as a worried signal. This research provides a useful quantitative base for scholars and practitioners to approach and discuss financial sustainability signals associated with a boost in corporate financial performance (section 5).

\section{The DuPont Equation and the Vulnerability Issue}

Among financial measures used to assess corporate performance ${ }^{1}$, the return on equity ratio (ROE) stands as very central, telling shareholders how effectively their money is being employed. ROE is calculated as follows:

(1) $R O E=\frac{N I}{E}$

${ }^{1}$ Such as EVA (Economic value added), MVA (Market Value Added), SVA (Shareholder Value Added) that are related to financial market performance. 
- NI Net income

- E Equity

The DuPont equation provides a classic framework for the decomposition of the ROE in causal factors. It was originally designed one hundred years ago for explaining the level of the return on assets (ROA - that is the operational profit upon the whole bulk of assets) through 2 drivers, the operational profit Margin and the asset Turnover

(2) $R O A=\frac{E B I T}{K}=\frac{E B I T}{P Q} \times \frac{P Q}{K}$

- EBIT Earnings before interest and tax

- K Capital

- PQ Sales

- $\frac{E B I T}{P Q}$ Operational profit margin

- $\frac{P Q}{K} \quad$ Asset turnover

With the decline of manager power and the rise of shareholder power in corporates, the DuPont formula shifted to a ROE Three-steps model (see Kharatyan, 2016), then was transformed in a five-steps DuPont Model by Hawawini and Viallet (1999) as following:

(3) $R O E=\frac{E B I T}{P Q} \times \frac{P Q}{K} \times \frac{K}{E} \times \frac{E B T}{E B I T} \times \frac{N I}{E B T}$

- EBT Earnings before tax

- E Equity

- $\frac{K}{E} \quad$ Leverage multiplier

- $\frac{E B T}{E B I T}$ Interest burden

- $\frac{N I}{E B T}$ Tax burden

Embedded in a conventional financial theory framework, the DuPont mathematical identity lies on the breaking down of the ROE into 5 components (drivers), operational profit, asset turnover, leverage multiplier, interest and fiscal burden bounded together in a multiplicative way. That makes DuPont a very useful, clear, reliable and flexible tool. The decomposition of the ROE in causal factors have been using by practitioners for identifying the source of strength and weakness in current performance of a corporate or by scholars for the financial analysis of sector performance in a given country. Until now, the lack of harmonization in accounting system has prevented researchers to extend the study to a large international panel analysis. Such limit is now off with the release of financial statement in IFRS (International Financial Reporting Standard) that has sharply reduced the asymmetry of accounting publicly disclosed information. Listed corporates are enforced to use fair value accounting for assessing their assets, to process their data in order to facilitate readings and analysis and to release consolidated financial statements in a cohesive and stable framework. Using the original DuPont equation to study the performance of a panel mixing corporates from different sectors and countries is then possible.

Our empirical study of causal factors in the DuPont equation sheds some interesting lights on the financial strategy for a panel of big corporates, especially on what have been selected by corporates to boost their financial performance. If every driver in the 
DuPont equation has exactly the same multiplicative impact on the financial performance, however they are not evenly ranked in their financial robustness/vulnerability consequences. The two first components of the DuPont equation, operational margin and asset turnover reflect "profitability" and "efficiency" ratio in the corporate performance. They both set up the ROA considered as a robust indicator by economists for driving scarce resource (Deloitte and Nyenrode white paper, 2016). The three other drivers, leverage multiplier, interest and fiscal burden are clearly associated to a higher degree of vulnerability as they are opportunistic short term factors that worsen off creditors and community positions in terms of well-being.

If we build a hierarchy ${ }^{2}$ of drivers according to their financial robustness ranking, first comes the asset turnover. This driver is linked with productivity (Bosh-Badia, 2010) and the sustainable growth paradigm (Higgins, 1977, Escalante et Al, 2006). A rising of this driver means a better efficient use of the capital amount: every stakeholder may be better off, it is a sustainable financial component, without any risk of damage in environmental, social and governance dimension. This robustness is reflected in the "sustainable DuPont formula" that measures the maximum rate of growth a company can reach without extra unit of capital. Ranking second comes the operating profitability, clearly associated with market matching for the company and with good operational management. However this second driver can be associated with a kind of vulnerability. That is the case when the operational profit worsen off employees (low wage) or suppliers (low raw material price) position. The three others drivers, leverage multiplier, interest and fiscal burden are clearly related with financial vulnerability. When the interest rate is below the ROA level, then increasing the leverage multiplier boosts the financial performance, rising the corporate indebtedness. The vulnerability comes from the disruption between ROA and ROE that paves the way to a good financial health illusion. The deleverage crisis of 2001 and 2008 demonstrated how such drivers are vulnerable along with the strong incentive for a corporate to use leverage and low interest rate to better off shareholders position. In the global age, some practitioners advocate the positive role of leverage as catalyst for fasting the spreading of new products and/or technology through the global market. That the reason why the leverage multiplier can't be associated with vulnerability only and should be credited with a king of robustness degree (see Table 1). The last vulnerable financial driver is fiscal burden, clearly an opportunistic factor associated with fiscal strategic behavior. A corporate can boost its ROE the same amount the tax rate is lowered, but at the cost of worsening off the community long term well-being position. Although some advocates that tax competition may better off the whole community in reducing monopoly power of the State (Public Choice theory), consensus is growing that the cost of corporate tax evasion has risen to an unsustainable level.

The following canvas is a ranking synthesis of robustness/vulnerability degree for every driver. This canvas will be useful for discussing empirical results from section 4 .

\footnotetext{
2 This point involves authors only. It is a canvas proposal helping to discuss results. The main point of the research is to assess which drivers have fueled the financial performance for the whole panel of corporates.
} 
Table 1: Drivers vulnerability canvas

\begin{tabular}{|l|c|c|}
\hline DRIVERS & ROBUSTNESS & VULNERABILITY \\
\hline Asset turnover & +++ & \\
\hline Operational profitability & ++ & - \\
\hline Low interest rate & + & -- \\
\hline Leverage multiplier & + & -- \\
\hline Low fiscal rate & & --- \\
\hline
\end{tabular}

Source: Authors

\section{Research Methodology}

We draw a statistical empirical analysis of corporate financial performance drivers for a panel of international corporates from 4 different markets, Paris (CAC 40), Frankfurt (DAX 30), Budapest (BUX 13) and Milano Stock Exchange (FTSE MIB).

\subsection{Sample and Data}

The panel data is set up of 43 Non-financial corporates ${ }^{3}$ with 21 French, $15^{2}$ German, 3 Hungarian and 4 Italian. The panel is selected as following:

- 21 French corporates: Accor, Air Liquide, Cap Gemini, Danone, Essilor, Kering, Legrand, L’oreal, Lvmh, Michelin, Orange, Pernod Ricard, Publicis, Renault, Safran, Saint-Gobain, Sanofi, Schneider Electric, Total, Valeo, Vinci.

- For the 15 German corporates: Adidas, Basf, Bayer, Bmw, Daimler, Deutsch Telekom, Deutsch-Lufthansa, Fresinius Medical Care, Henkel, K+S, Linde, Merck, Sap, Siemens, Wolkswagen.

- For the 4 Italian corporates: Campari, Enel, Eni, Fiat

- For the 3 Hungarian corporates: Magyar Telecom, Mol, Richter Gedeon.

15 Industries are represented in the panel: Aero, Building, Car, Telecom, Chemical, Energy, Electric, Consumer, Luxury, Engineering, Infrastructure, Media, Data Processing, Health.

Data are set up of 258 observations (panel data) directly hand-collected from financial reporting disclosed by listed corporates and freely available on internet. As previously stated, we make the hypothesis that such accounting materials are now both reliable and standardized enough to provide a secure source of data for the metrics. The broad implementation of IFRS along with the improvement in accounting rules framework dismissed by IAS board has strongly reduced the asymmetry of information. Consolidated financial statement data are assumed to be exploitable for research purpose. Data in balance sheet boards are expressed in fair value for the asset and liabilities (market value opposed to carrying amount) that provide us with comparable and robust data in the study. Data are submitted to a delay of one year for their registration as the fair value for "goodwill", a large part of intangible asset needs one year

\footnotetext{
${ }^{3}$ Initially our sample was set up of 49 non-financial corporates with Arcelor Mital, Engie, Vivendi, E-on, Thyssen Krupp and Telekom Italia. Because of data problems with some outliers and because of log transformation, we have chosen to drop them from the empirical study.
} 
to be established ${ }^{4}$. It explains why the study is limited to the period 2012-2017. Before 2012 data were not all expressed in the same IFRS framework with a clear lack of accurate treatment for the goodwill that is a crucial component of big corporates asset value. The period 2012 - 2017 is an interesting period to study given its questionable financial boom.

\subsection{Metrics built-up}

Data are used to build the 6 Metrics identified in (3), ROE, expressed as the ratio of net income upon equity established in percent, operating profit margin expressed as the ratio Ebit/Sales established in percent, asset turnover expressed as the ratio Sales/Total assets, leverage Multiplier expressed as the ratio of total of Asset/Equity, interest burden expressed as the ratio Ebt (Earnings before Tax) /Ebit (Earnings before interest and tax), and fiscal burden expressed as the ratio of Net income/Ebt. Operating profit margin and asset turnover are expressed in percent, leverage is a multiplier ratio and interest and fiscal burden are measures expressed between 0 and 1, so that the closer to 1 for both metrics, the greater the ROE. We don't take into account of any inflation nor perimeter change. The empirical study focusing on the relative role of drivers in the performance, all expressed in ratios, the lost in information accuracy is somehow limited. For every individual is checked that metrics is built in a cohesive way, meaning that the product of factors is equal to the ROE.

\subsection{Analysis methodology}

We draw a statistical analysis of performance drivers for the whole sample in three steps. First, we process the Log median ${ }^{5}$ measures for the ROE and its five drivers on the whole sample and spot them on a time-path graphics (graphic 1 and table 2). The Log additivity provides an eye-catching analysis of which and how driver have fueled the ROE level. Secondly, we measure which and how drivers has influenced the ROE time variation (table 3). After indexing data from 2012, we calculate yearly Log variation ${ }^{6}$. Pairwise Pearson correlation coefficient ${ }^{7}$ (PCC) gives then a clear measure for every driver of its influence on the ROE time variation during the period. PCC highlights the factors which have exerted a positive or negative influence on ROE and measure how the ROE variance is explained by every driver variance. Thirdly, a multiple linear

\footnotetext{
${ }^{4}$ It means the data in the 2013 financial reporting is of better quality for the year 2012 than the data in the 2012 financial reporting.

${ }^{5}$ For a visual plot of the drivers influence through the 2012-2017 period, the median analysis is better than an average analysis. With the multiplicative shape of the equation, there may be a strong distortion between the product of average and the average of products.

6 While processing using accounting data, one must take care when there are two consecutive less sign. The second less sign could be a reduction of the lost meaning that result is a positive growth

7 The Pearson correlation report has the following mathematical formula: $r=\frac{\sum(x-\bar{x})(y-\bar{y})}{\sqrt{\sum(x-\bar{x})^{2}(y-\bar{y})^{2}}}$ where $\mathrm{r}=$ the Pearson Correlation report, $\mathrm{x}$ and $\mathrm{y}$ represents the indicators' average value on the same distribution range. The value of the correlation report is between -1 and 1 , so that if $\mathrm{r}$ is close to 0 there is a lack of correlation, if is close to -1 or 1 there is a strong negative (-1) or direct (1) correlation.
} 
regression is processed using the 215 observations in variation (table 4) ${ }^{8}$ and in level (table 5). Metrics index are used. Then OLS method on the pooled sample provides for every driver the value and significance of its impact on ROE performance during the period. The dependent variable (ROE) is regressed on the following independent variables (in variation then in level): operational profit margin (OP), asset turnover (AT), leverage multiplier (LM), interest burden(IB) and fiscal burden (FB) and the model ${ }^{9}$ is as followed:

$$
R O E_{i, t}=\beta_{1} O P_{i, t}+\beta_{2} A T_{i, t}+\beta_{3} L M_{i, t}+\beta_{4} I B_{i, t}+\beta_{5} F B_{i, t}+\varepsilon_{i, t}
$$
$(+)$
$(+)$

Where $\beta_{1}, \ldots, \beta_{5}$ are the correlation coefficients attached to every independent variable. The indexes "i,t" are for corporate $\mathrm{i}=1$ to 43 in period $\mathrm{t}=2013, \ldots, 2017$. $\varepsilon_{\mathrm{i}, \mathrm{t}}$ is for the error term that is supposed to satisfy normal distribution. The sign (+) are expected sign of coefficient attached with variable (level). Regression results measure the influence of every driver upon the corporate performance, a useful measure for discussing the performance vulnerability. We also disaggregate the whole sample according to countries and following sectors: Car, Consumer, Energy and Health. Regression results highlight the relationships between drivers and ROE variation for those specific subsamples.

\section{Results}

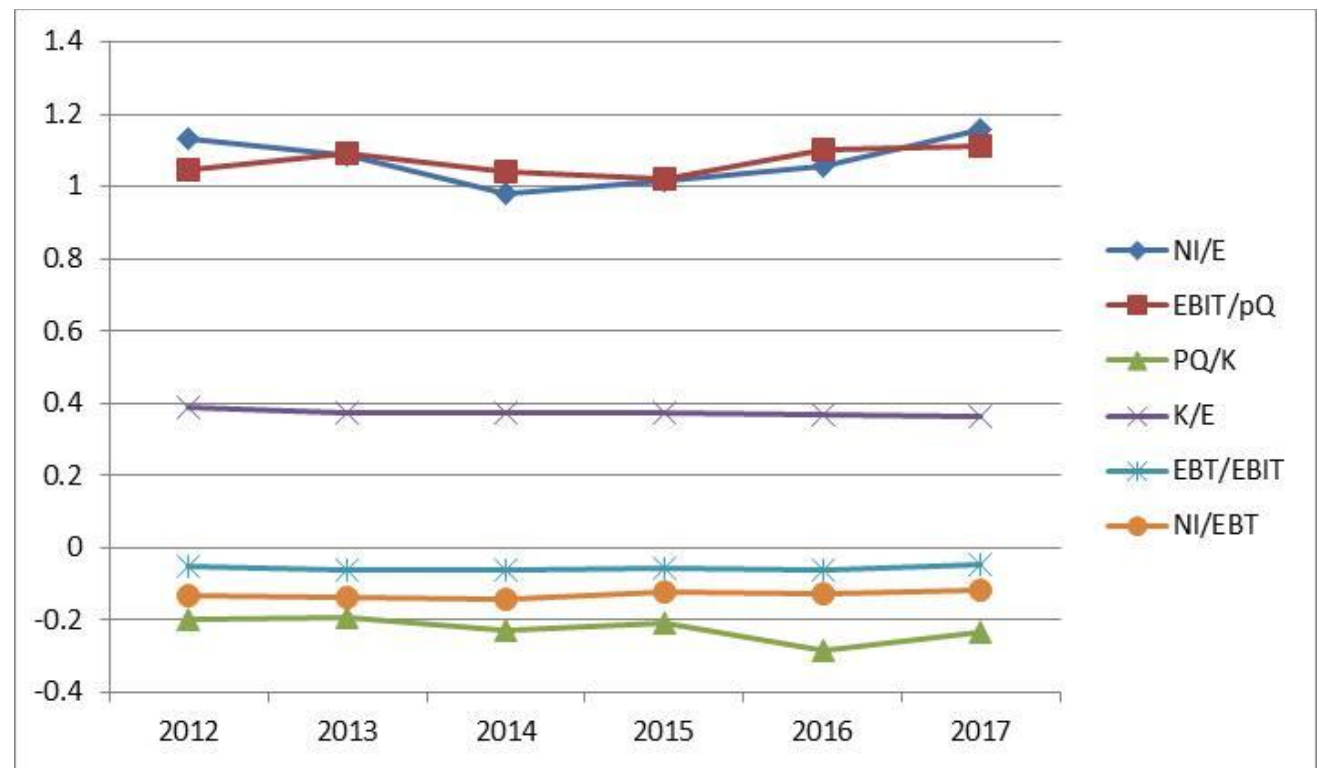

Graphic 1: Time-path of the median in Log for the five drivers and the ROE (NI/E)

Source: Authors

${ }^{8}$ In variation but not in $\log$. A double log model should not be used as coefficient will be expressed in elasticity. Or the model is an experimental one, meaning that any variation in one independent variable has an elasticity of 1 on the dependent variable.

${ }_{9}^{9}$ We select a no constant model as better reflecting the true model. 
Table 2: Median in Log measure for the five drivers and the ROE (NI/E)

$\begin{array}{ccccccc} & \text { NI/E }(\%) & \text { EBIT/PQ }(\%) & \text { PQ/K } & \text { K/E } & \text { EBT/EBIT } & \text { NI/EBT } \\ 2012 & 13,62 & 11,15 & 0,63 & 2,45 & 0,88 & 0,74 \\ 2013 & 12,20 & 12,28 & 0,64 & 2,36 & 0,86 & 0,73 \\ 2014 & 9,57 & 11,03 & 0,59 & 2,364 & 0,87 & 0,72 \\ 2015 & 10,34 & 10,51 & 0,62 & 2,359 & 0,87 & 0,75 \\ 2016 & 11,32 & 12,58 & 0,52 & 2,34 & 0,87 & 0,74 \\ 2017 & 14,43 & 12,97 & 0,58 & 2,30 & 0,89 & 0,77\end{array}$

Source: Authors

The graphic clearly shows which and how drivers have fueled the ROE level during the period. The use of Log measurement in the graphic is accurate as the vertical sum of drivers gives a result somehow close to the ROE (while not exactly the ROE). The table 2 gives driver median value (not expressed in Log) as a clear measure of the evolution for every driver and the ROE

The eye catching graphic 1 coupled with table 2 show that the "profitability" driver (Ebit/PQ) used to play a major role in the ROE level, ever to boost the ROE (2016, 2017) or to sustain it when others drivers have declined (2013). A striking result is the steady drop in the "efficiency" driver (PQ/K - green line) until 2016 although there is a sudden jump of $12 \%$ in 2017. Interest and fiscal burden (Ebt/Ebit, NI/Ebt) has highly influenced the ROE performance, their multiplicative effect bringing something like 4 points in the ROE. Lower interest rate (from 4,5\% in 2012 to nearly 1\% in 2017) coupled with fiscal strategy have improved the ROE performance. An interesting point is the steady and sharp decline in the leverage multiplier $(\mathrm{K} / \mathrm{E}$, purple line) meaning that corporates have not fully exploited the leverage potential associated with the decrease in interest rate. This point worth to be highlighting as very questionable, is it a hysteresis effect of the leverage crisis, is it the signal of a responsible behavior from manager and shareholder? Anyway, the leverage multiplier has been voluntary reduced despite the opportunity to benefit of decreasing interest rate. 2017 may appear as a turning point in the trajectory as the ROE rising is fueled through a rising in "efficiency" but most of all by an "interest and fiscal" opportunity effect.

Table 3: Pairwise Pearson correlation coefficient (PCC) matrix in yearly log variation (obs=215) (column 1 - PCC between ROE and drivers)

\begin{tabular}{|l|cccccc|}
\hline & NI/E & EBIT/PQ & PQ/K & K/E & EBT/EBIT & NI/EBT \\
\hline NI/E & 1.0000 & & & & & \\
EBIT/PQ & 0.3775 & 1.0000 & & & & \\
$\mathrm{PQ} / \mathrm{K}$ & 0.0525 & -0.1021 & 1.000 & & & \\
$\mathrm{~K} / \mathrm{E}$ & -0.0924 & -0.0589 & -0.1577 & 1.0000 & & \\
$\mathrm{EBT} / \mathrm{EBIT}$ & 0.3969 & -0.2813 & 0.1038 & -0.1465 & 1.0000 & \\
NI/EBT & 0.5169 & -0.2217 & -0.1313 & -0.0443 & -0.1262 & 1.0000 \\
\hline
\end{tabular}

Source: Authors

In the first column, the Pairwise Pearson correlation coefficients matrix calculates how the yearly variance in $\mathrm{ROE}$ is explained by every driver variance, then measuring the positive or negative influence of every driver on the ROE (NI/E) in evolution. The 
strongest positive influence comes from the fiscal burden driver that explains more than $50 \%$ of the variance of the ROE. Coupled with the interest burden, it is clear that opportunistic drivers explains the larger share of ROE variance. "Profitability" comes in third position explaining $37 \%$ of ROE variation. If this driver is important in explaining the ROE level (see table 5), it is not the most influential in the performance variation during the period. More striking, the "efficiency" driver (PQ/K) was not very influential on the performance. It is not a good signal as this driver is considered as the more robust in finance performance (see section 2). Last, a good point for finance sustainability comes from the Leverage $(\mathrm{K} / \mathrm{E})$ that has played a negative role (PCC $=-0.09$ ) as performance booster. This measure is on line with the negative slope of $\mathrm{K} / \mathrm{E}$ displayed on graphic 1. Although the great opportunity to use leverage multiplier through a low interest rate windfall and a high operational profit margin for increasing shareholder performance, it seems that corporates has restricted themselves to use it. To sum up, fiscal strategy, interest opportunity and profitability are the drivers of the ROE variation during the period and have fueled the corporate shareholder performance, while efficiency and leverage have both played minor (see negative for leverage) impact in variation.

Table 4: OLS Regression of ROE (in variation) - Overall Results and Breakdown by countries and sectors, no constant

\begin{tabular}{|c|c|c|c|c|c|c|c|c|c|}
\hline Regression & 1 & 2 & 3 & 4 & 5 & 6 & 7 & 8 & 9 \\
\hline Country/Sector & Overall & France & Germany & Italy & Hungary & CAR & CONS & ENERGY & HEALTH \\
\hline Dependent & $\Delta(\mathrm{NI} / \mathrm{E})$ & $\Delta(\mathrm{NI} / \mathrm{E})$ & $\Delta(\mathrm{NI} / \mathrm{E})$ & $\Delta(\mathrm{NI} / \mathrm{E})$ & $\Delta(\mathrm{NI} / \mathrm{E})$ & $\Delta(\mathrm{NI} / \mathrm{E})$ & $\Delta(\mathrm{NI} / \mathrm{E})$ & $\Delta(\mathrm{NI} / \mathrm{E})$ & $\Delta(\mathrm{NI} / \mathrm{E})$ \\
\hline \multirow[t]{2}{*}{$\Delta(\mathrm{EBIT} / \mathrm{PQ})$} & 0.0251 & $0.0147 * * *$ & 0.0446 & 1.037 & $0.6528^{* * *}$ & $0.7980^{* * *}$ & -0.1795 & $0.6242 * * *$ & $0.7649 * * *$ \\
\hline & {$[0.0215]$} & {$[0.00564]$} & {$[0.2690]$} & {$[0.7768]$} & {$[0.1099]$} & [0.1862] & {$[0.1451]$} & {$[0.1437]$} & {$[0.1940]$} \\
\hline \multirow[t]{2}{*}{$\Delta(\mathrm{PQ} / \mathrm{K})$} & $2.2364 * *$ & 0.5159 & $-1.79 * * *$ & 3.788 & 3.1511 & -1.000 & -0.0553 & 3.8786 & -0.1839 \\
\hline & [1.1886] & {$[0.4977]$} & {$[0.4$} & [3.4134] & {$[3.6867]$} & {$[0.6233]$} & {$[0.3555]$} & [3.7344] & {$[0.2535]$} \\
\hline \multirow[t]{2}{*}{$\Delta(\mathrm{K} / \mathrm{E})$} & $-2.498 * *$ & $-1.181 * * *$ & $-1.196 * * *$ & -3.283 & -3.6039 & 0.2388 & -0.2146 & 0.0751 & $-0.556^{* *}$ \\
\hline & [1.1758] & [0.4919] & {$[0.351$} & [3.2672] & [4.5635] & {$[0.5206]$} & [0.3898] & [3.7606] & [0.2147] \\
\hline$\Delta(\mathrm{EBT} / \mathrm{EBIT})$ & $\begin{array}{c}0.3092 * * * \\
{[0.0851]}\end{array}$ & $\begin{array}{c}0.3601 * * * \\
{[0.0375]}\end{array}$ & $\begin{array}{c}2.2440 * * * \\
{[0.1098]}\end{array}$ & $\begin{array}{c}0.0293 \\
{[0.0944]}\end{array}$ & $\begin{array}{c}0.6227 \\
{[0.7839]}\end{array}$ & $\begin{array}{c}0.6284 * * * \\
{[0.0714]}\end{array}$ & $\begin{array}{c}0.699 * * * \\
{[0.2743]}\end{array}$ & $\begin{array}{c}0.0751 \\
{[0.1000]}\end{array}$ & $\begin{array}{c}0.4659 \\
{[0.3328]}\end{array}$ \\
\hline \multirow[t]{2}{*}{$\Delta(\mathrm{NI} / \mathrm{EBT})$} & $0.84884 * * *$ & $1.2250^{* * *}$ & $1.6647 * * *$ & $-0.38^{* * *}$ & $-0.6313^{* *}$ & $0.3137 * * *$ & $0.7802^{* * *}$ & $-0.393 * * *$ & $0.5545^{*}$ \\
\hline & [0.0593] & [0.1752] & [0.3149] & [0.0944] & [0.8232] & [0.0899] & {$[0.2033]$} & [0.1231] & {$[0.1772]$} \\
\hline $\mathrm{N}$ & 215 & 105 & 75 & 20 & 15 & 35 & 35 & 20 & 25 \\
\hline Adj. R-Squared & 0.5437 & 0.9808 & 0.9487 & 0.6358 & 0.7371 & 0.9475 & 0.9366 & 0.6418 & 0.9678 \\
\hline
\end{tabular}

$\mathrm{p}$-value in brackets

$={ }^{*} \mathrm{p}<0.1,{ }^{* *} \mathrm{p}<0.05,{ }^{* * *} \mathrm{p}<0.01$

Source: Authors

In the first column is displayed the econometric relationship in variation between every of the five drivers and the ROE performance during the period and for the whole sample. Other columns display breakdowns regressions by countries and sectors. OLS method with no constant constraint is used. For the whole sample, the most significant drivers explaining variation in $\mathrm{ROE}$ are tax and interest burden. This result confirms the table 3 statement that opportunistic (then vulnerable) variables have played a major role in boosting the ROE. The significant negative role of the leverage multiplier is also confirmed in line with results from graphic 1, tables 2 and 3. This result sounds like a good point for finance sustainability, meaning that corporates, through a dominant deleverage strategy, has restricted themselves from boosting the ROE at higher level, and 
have embraced a long run perspective. The econometric relationship between the efficiency driver and ROE seems not on line with the result from table 3. As we use data variation, the regression captures the fitness between ROE and asset turnover as they both goes down and up. More surprising is the lack of significance in the profitability driver coefficient. This driver doesn't explain variation in ROE during the period although PCC has demonstrated a correlation. Profitability is obviously an important ROE driver that has probably played a countercyclical role in 2012-2013 preventing a deeper drop in the ROE (see graphic 1). When the regressions are computed in level (table 5), drivers are all significant and the profitability driver plays a significant role.

Table 5: OLS Regression of ROE (in level) - Overall results and Breakdown by countries and sectors, no constant

\begin{tabular}{|c|c|c|c|c|c|c|c|c|c|}
\hline Regression & 1 & 2 & 3 & 4 & 5 & 6 & 7 & 8 & 9 \\
\hline Country/Sector & Overall & France & Germany & Italy & Hungary & CAR & CONS & ENERGY & HEALTH \\
\hline Dependent & $(\mathrm{NI} / \mathrm{E})$ & (NI/E) & $(\mathrm{NI} / \mathrm{E})$ & $(\mathrm{NI} / \mathrm{E})$ & (NI/E) & $(\mathrm{NI} / \mathrm{E})$ & (NI/E) & (NI/E) & (NI/E) \\
\hline \multirow[t]{2}{*}{ EBIT/PQ } & $0.4093 * * *$ & $0.2008^{* * *}$ & 0.0160 & $0.8221 * * *$ & $1.2750^{* * *}$ & $0.9066^{* * *}$ & -0.1234 & $1.6599 * * *$ & 0.1473 \\
\hline & [0.04914] & {$[0.07250]$} & [0.0911] & [0.1336] & [0.2662] & [0.1755] & {$[0.1330]$} & [01606] & {$[0.2107]$} \\
\hline \multirow[t]{2}{*}{$\mathrm{PQ} / \mathrm{K}$} & $4.9940^{* * *}$ & $4,252 * *$ & $3.627 * *$ & $17.871^{* * *}$ & $14.896^{* *}$ & 6.4691 *** & 1.5939 & $8.444 * * *$ & 1.6985 \\
\hline & [1.3042] & [1.7884] & [1.6967] & [5.9060] & [7.8083] & [2.2289] & {$[2.9540]$} & [2.3173] & [4.4076] \\
\hline \multirow[t]{2}{*}{$\mathrm{K} / \mathrm{E}$} & $0.6060 * *$ & 0.2875 & -0.1558 & $-1.3129 *$ & -3.1746 & -0.3636 & $-1.8908^{* *}$ & $-5.201^{* * *}$ & $3.3824 * * *$ \\
\hline & [0.2943] & [0.5088] & [0.3974] & [0.8033] & [2.9425] & [0.4272] & {$[0.9717]$} & [0.9135] & [0.9205] \\
\hline \multirow[t]{2}{*}{ EBT/EBIT } & $1.4000^{* * *}$ & $1.9579 * * *$ & $-10.12^{* * *}$ & $-10.60^{* * *}$ & -10.9738 & $2.6240^{* *}$ & $13.86^{* * *}$ & 0.5892 & $-8.6639 *$ \\
\hline & {$[0.3273]$} & [03467] & [1.3294] & [2.96966] & [1.6897] & [1.0665] & {$[4.1529]$} & [1.1346] & [4.6486] \\
\hline \multirow[t]{2}{*}{ NI/EBT } & $1.1178^{* *}$ & $6.0780^{* * *}$ & 3.3781 & 0.5854 & $-10.520^{* *}$ & 1.5037 & $7.144^{* * *}$ & $-0.717 * *$ & $9.3472^{* * *}$ \\
\hline & {$[0.4908]$} & [11938] & [2.3151] & [0.4381] & [4.9943] & [1.7312] & [1.07704] & [0.3787] & [1.8634] \\
\hline $\mathrm{N}$ & 258 & 126 & 90 & 24 & 18 & 42 & 42 & 24 & 30 \\
\hline Adj. R-Squared & 0.8029 & 0.8403 & 0.9165 & 0.7974 & 0.7257 & 0.9267 & 0.9397 & 0.8610 & 0.9398 \\
\hline
\end{tabular}

Whatever regressions are (variation and level), breakdowns in countries and sectors deal with the heterogeneity of the whole sample and show some interesting comparative results. For example, opportunistic drivers are more used in French corporates than in German one. Some remarks could also been drawn for the comparison within sectors. Cons and Health sectors have used more opportunistic drivers for boosting the ROE than Energy and Car sectors.

\section{Conclusion and implications}

Big international corporates used to claiming that they favor sustainable shareholder value through their strategically selected drivers, and the "sustainability" growth is part of their disclosed policy since sustainability reports has been an integral part of their reporting. Nonetheless questions raise about the reality in "sustainability" of the recent rise in corporate performance, as the ROE reached a 14\% in 2017 compare to a $9 \%$ in 2014. Lot of studies have focused upon the analysis of value drivers (Bistrova et al, 2014, Moir et al, 2007). Our study highlights financial drivers from a classical DuPont equation to measure how the performance was fueled. Having selected a large sample of big corporates from EU using their financial statements established in IFRS, we 
hypothesized that a "vulnerability" analysis can be drawn through the study of classical financial ratios. Robustness/vulnerability in financial ratios are ranked as following (see canvas section 2) asset turnover (PQ/K), operational margin profit (Ebit/PQ), interest burden (Ebt/Ebit), leverage multiplier (K/E), fiscal burden (NI/Ebt). Our results clearly show that the more active drivers explaining ROE variations are the fiscal burden, interest burden and operating profit margin (graphic 1 and table 3 for the last driver). Using the canvas built in section 2, it appears that the two firsts are rather financially vulnerable while the profitability is ranked a robust financial driver. A great point in favor of the robustness of the financial performance is the deleverage multiplier effect observed for every market and sector (the decreasing of the ration $\mathrm{K} / \mathrm{E}$ ). It was a surprise as opportunities to boost the performance through a decreasing interest rate and a rather strong operational profit was real. This good news is somehow balanced by the drop in asset turnover during a long stretch of the studied period (except for 2017), a bad signal as this driver is clearly the less vulnerable one. In conclusion the good performance in the 2012-2017 period was rather vulnerable, as it was largely explained by opportunistic then vulnerable drivers (a drop in fiscal and interest burden). However, good signals came from leverage multiplier (that badly injured financial corporate performance in 2001 and 2008) as empirical measurement show a deleverage process in a context of great opportunism to use leverage multiplier. Does it mean that shareholders and managers have accepted on short term a lower ROE to get in a more sustainable long term financial performance? Our study can't go that far. Our study was beyond the scope of highlighting the situation of customers, employees, suppliers in sustainable value creation. Nonetheless, our study shows the interesting implications of the DuPont tool. Our research has demonstrated that the financial vulnerability issue can be studied at corporate level with publicly disclosed financial reporting data. That's a good point to study this issue as close as possible of the entity that creates shareholder value. Secondly, DuPont equation is a flexible tool that can be exploited for further investigations in financial sustainability issue. Through breakdowns, the DuPont "profitability" could be disaggregated some steps further to integrate wage component in operational profit margin, then study the employee stakeholder oriented issue in an instrumental DuPont model. The disaggregation could also affected the asset turnover that is the product of a ratio "customer" price upon "supplier" price multiplied by capital productivity ratio. Those last remarks pave the way for a deeper "sustainable" research issue with DuPont formula as employees, customers and suppliers can be introduced in a stakeholder analysis. DuPont, despite its 100 years old still seems a very appealing tool for practitioners and scholars.

\section{References}

Bistrova, J., Titko, J., Lace, N. (2014) Sustainable shareholder value: Analysis of value drivers, Economics and Management, 19 (2), 129-139.

Bosh-Badia, M.T., (2010) Connecting productivity to return on Assets through financial Statements: extending the DuPont method. International Journal of Accounting and Information management, 18, 2, $92-104$.

Burja, V. and Marginean, R. (2014) The study of factors that may influence the performance by the DuPont analysis in the furniture industry, Procedia Economics and Finance 16, 213-223 
Castro, N.R. and Chousa, J.P. (2006) An Integrated Framework for the Financial Analysis of Sustainability, Business Strategy and the Environment, 15, 322 - 333

Deloitte white paper, (2016) Good Governance driving Corporate Performance? A meta-analysis of academic research\&invitation to engage in the dialogue, December 2016 Nyenrode Business University https://www2.deloitte.com/content/dam/Deloitte/nl/Documents/risk/deloitte-nlrisk-good-governance-driving-corporate-performance.pdf

Epstein, M.J., Roy, M.J., (2001) Sustainability in action: Identifying and measuring the key Performance drivers, Long Range Planning, 34, 585-601.

Escalante, C.L., Turvey, C.G., Barry, P.J. (2006). "Farm Business Decisions and the Sustainable Growth Challenge paradigm." Agricultural Finance Review 69,2:228-247.

Fama, E.F., French, K.R. (2015) A five-factor asset pricing model, Journal of Financial Economics, vol 116, pp. $1-22$

Friedman, M. (1970, September 13) The social responsability of business is to increase its profits. The New York Times Magazine.

Galant, A., Cadez, S. (2017) Corporate social responsability and financial performance relationship: a review of measurement approaches, Economic Research-Ekonomiska Istrazivanja, 30:1, 676-693.

Hawawini, G.A., and Viallet, C., (1999) Finance for executives: Managing for Value Creation. Cincinnati. South Western College Publication

Higgins, R.C. (1977). How Much Growth Can a Firm Afford? Financial Management 6,3: 7-16.

Kharatyan D., (2016) Ratios and Indicators that determine return on equity. Final Dissertation presented to Instituto Politécnico de Bragança.

Kijewska, A., (2016) Deteminants of the Return on Equity Ratio (ROE) on the Example of Companies from Matallurgy and Mining Sector in Poland. Metalurgija 55 (2016), 285-288.

Kiran R., Sharma A. (2011) Corporate Social Responsibility: A Corporate Strategy for New Business Opportunities, Journal of international Business Ethics, Vol 4, N¹, 10 - 17

Jensen, M. C. (2001). Value Maximization, Stakeholder Theory and the Corporate Objective Function. Journal of Applied Corporate Finance, 14(3), 2001, 8-2.

Lozano R. (2015) An Holistic perspective on Corporate Sustainability Drivers. Corporate Social Responsability and Environmental Management, vol 22, issue 1, 32-44.

Moir, L., Kennerley, M. \& Ferguson, D. (2007). Measuring the Business Case: Linking Stakeholder and Shareholder Value. Corporate Governance, 388-400. http://dx.doi.org/10.1108/14720700710820470

Mubin, M., Iqbal, A. A., Hussain, A. (2014). Determinant of Return on Assets and Return on Equity and Its Industry Wise Effects: Evidence from KSE (Karachi Stock Exchange). Research Journal of Finance and Accounting, 5(15), 148-157

Porter, M.E., and Kramer, M.R., (2011) The Big Idea: Creating Shared Value. Harvard Business Review, 89, $2-17$.

Rezaee Z., (2016) Business Sustainability Research: A theoretical and intregrated perspective, Journal of Accounting Litterature, 36, 48-64.

Sabbaghi, O., Pae, Y., Sabbaghi N. (2016) The sustainable Growth Rate, DuPont analysis, and the crossSection of Returns, Working Paper

Waal, A. (2008). The End of Shareholder Value Thinking. Business Strategy Series, 9(6), 316-323.

WCED (1987) World Commission on Environment and Development. Our Common Future. Oxford University Press, Oxford 